Gazi University
Journal of Science
$\mathrm{http} / /$ dergipark.gov.tr/gujs

\title{
Monitoring of the Chemical Composition of Rainwater in a Semi-Urban Area in the Northern West of Turkey
}

\author{
Baris GUZEL* \\ Environment and Cleaner Production Institute, Marmara Research Center, 41470, Gebze, Kocaeli, Turkey
}

\author{
Highlights \\ - Rainwater is excessively affected from sources of urban and industrial emissions. \\ - High concentration of $\mathrm{Ca}^{2+}$ and $\mathrm{Na}^{+}$and the presence of $\mathrm{SO}_{4}{ }^{2-}$ were detected. \\ - High amounts of $\mathrm{Al}, \mathrm{Fe}, \mathrm{Ba}, \mathrm{Mn}, \mathrm{B}, \mathrm{Sr}$ and $\mathrm{Cu}$ were observed in most of the samples. \\ - The main pollution sources are construction, agricultural, vehicle and local industrial activities.
}

\section{Article Info}

Received: $26 / 04 / 2020$ Accepted: 18/06/2020

\section{Keywords}

Chemical composition Major ions

Trace elements

Rainwater

Semi-Urban area

\begin{abstract}
In this study, the collection of twenty-three samples were carried out from October 2019 to March 2020 to describe the chemical composition of the rainwater and possible sources of atmospheric emissions (major ions and trace elements) and finally to establish data of those species in Gebze, Kocaeli. The $\mathrm{pH}$ range in these samples varied between 5.81 and 7.27 (average $\mathrm{pH}: 6.51$ ). $\mathrm{pH}$ of the samples was predominantly neutral. The EC values of the 23 rainwater samples changed within the range of $22.1 \mu \mathrm{S} \mathrm{cm}^{-1}-126.2 \mu \mathrm{S} \mathrm{cm}^{-1}$ (average EC: $63.0 \mu \mathrm{S} \mathrm{cm}^{-1}$ ). Dealing between EC values and $\mathrm{Ca}^{2+}$ concentrations of samples (good positive correlation $\left(\mathrm{R}^{2}=0.84\right)$ ) in graph) can be thought that dust particles, which include a significant amount of calcite and similar type of minerals, act as carriers for soluble solid materials in atmosphere. The order of percentage contribution of each ion species to total ion composition in rainwater was: $\mathrm{Ca}^{2+}>\mathrm{Na}^{+}>\mathrm{SO}_{4}{ }^{2-}>\mathrm{Cl}^{-}$ $>\mathrm{Mg}^{2+}>\mathrm{NO}_{3}{ }^{-}>\mathrm{NH}_{4}{ }^{+}>\mathrm{K}^{+}>\mathrm{PO}_{4}{ }^{3-}>\mathrm{NO}_{2}->\mathrm{F}^{-}$. The most abundant ions $\left(\mathrm{Ca}^{2+}, \mathrm{Na}^{+}\right.$and $\left.\mathrm{SO}_{4}{ }^{2-}\right)$ contributed approximately $45 \%, 13 \%$ and $11 \%$, respectively. High $\mathrm{Ca}^{2+}$ profile points out construction activities, agricultural activity and various industrial activities producing building materials around the sampling site. The trend of trace elements $\left(\mu \mathrm{g} \mathrm{L}^{-1}\right)$ based on concentrations during the whole study period was: $\mathrm{Al}(34.52)>\mathrm{Fe}(26.03)>\mathrm{Ba}(20.67)>\mathrm{Mn}(18.06)>\mathrm{B}(16.39)$ $>\mathrm{Sr}(16.27)>\mathrm{Cu}(10.42)$, respectively. Consequently, concentrations of ions and trace elements in rainwater samples collected in this study were compared with previous studies from similar locations in Turkey and in other countries.
\end{abstract}

\section{INTRODUCTION}

Air pollution can be explained as the presence of more than one pollutant in the atmosphere in the form of dust, gas, smoke, water vapour that will harm human, plant and animal life depending on time and quantity $[1,2]$. When the pollutants in the atmosphere are detailed in terms of their sources, processes and pollution effects, they are defined as primary pollutants that are released to the atmosphere from a particular source, and secondary pollutants to those that occur as a result of chemical interactions in the atmosphere. Geographical region, emission mixture of air pollutants and atmosphere chemistry play a critical role in the formation of these pollutants. The size of the pollutants varies depending on their sources and these pollutants spread to the atmosphere from a natural or anthropogenic (human-sourced) source [3]. Natural sources can be exemplified as volcanic activities, forest decomposition, degradation products of animal and plant waste, earth dust (mineral aerosol) and marine spray [4-8]. Anthropogenic emissions are originated from sectors such as electricity production, industry, transportation, waste etc. [9-12].

The examination of atmospheric composition of a place is important for air pollution control [13,14]. In the investigation of this pollution, rainfall and similar weather events are the most important ways to transfer 
pollutants from the atmosphere to aquatic and terrestrial ecosystems [15]. Rainwater provides information on the level of local emissions, pollutant transport, climatic conditions and drop size [16,17] and its chemical composition alters according to meteorological conditions, sources and long-range transport of air masses [18-20]. In this sense, the determination and characterization of the chemical contents of rainwater also provide important supports and knowledge on primarily health problems and natural ecosystem issues such as acidification of water bodies and soils, imbalances in the food cycle and ecosystem efficiency [4, 21-23]. In the literature, recent studies on this subject have shown that rainfall (wet precipitation) in an area is an important indicator in the determination of the level of pollutants in the chemical composition in urban regions [3, 14, 24-33].

In view of these studies, this work was carried out in the semi-urban area in the northern west of Turkey, from October 2019 to March 2020, with the following goals: (i) describe the chemical composition of the rainwater; (ii) identify possible sources of atmospheric emissions (major ions and trace metals); and (iii) establish data of those species in the monitoring region.

\section{MATERIALS AND METHODS}

\subsection{Sampling Region and Meteorological Data}

Sampling location is situated in Gebze district of Kocaeli and the rainwater sampling was performed on outdoor terrace of The Scientific and Technological Research Council of TURKEY Marmara Research Center (TUBITAK MAM) Environment and Cleaner Production Institute (4047'23" N, 29 27'24'E) (Figure 1). After each rainwater sampling, the plastic sample container was washed with diluted $\mathrm{HCl}$ and ultra-pure distilled water and dried before using. It was ensured that the samples did not contaminate each other. The most important feature of the sampling point includes many large and medium-sized industrial establishments. Moreover, there are many organized industrial zones, mainly Dilovası Organized Industrial Zone around the sampling point. It is approximately $8 \mathrm{~km}$ away from Dilovas 1 Organized Industrial Zone, which is one of the most important industrial regions of Turkey and especially includes in the metal and chemical industrial establishments. Thus, it is significantly affected by industrial contamination sources. Furthermore, it is considerably affected by the pollution from vehicles between Istanbul and Kocaeli. The collection of twenty-three samples were carried out from October 2019 to March 2020 with the help of a manual system including plastic funnel, one liter plastic container and handle. The collection of samples was carried out in the occurrence of precipitation event (randomly) during the sampling period. When the rain event began, the sampling vessel was placed in the sample station, sampling was not carried out at such times as strong wind, and heavy rain events would cause dry accumulation to the samples. Collected rainwater samples were kept at $+4{ }^{\circ} \mathrm{C}$ in a refrigerator until further analysis.

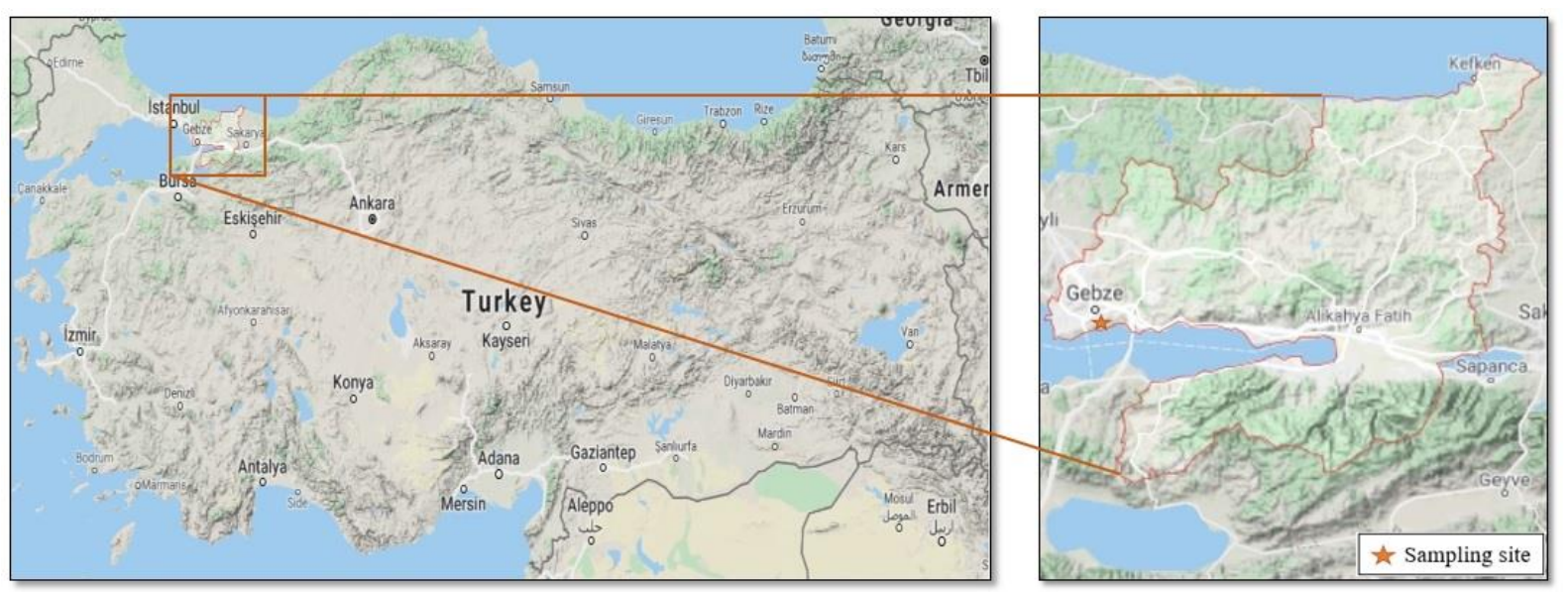

Figure 1. Rainwater sampling site in Kocaeli, Turkey

Gebze district of Kocaeli province has a transition climate between the Black Sea and the Mediterranean climates due to its location, and it has a warm and temperate climate. The winter months are much rainier 
than the summer months. The coldest months of the year are January and February and the temperature does not exceed $-5^{\circ} \mathrm{C}$ during this period. The average precipitation in study area (Gebze) is $816.4 \mathrm{~mm}$ and the average annual temperature is $14.8^{\circ} \mathrm{C}$. Meteorological data for sample collection dates are given in Table 1. Meteorological data belonging to the sampling study were obtained from the official website of the General Directorate of Meteorology (GDM) [34]. Wind directions are of great importance in this and similar air pollution source and status assessment studies. As seen in Table 1, wind directions are mostly NNW, WSW and SE at the sampling period. Since there is no industrial zone in the WSW and SE wind directions, it is thought that there will be no pollution transport. Pollution is likely to be carried as there are found different type of industrial activities in the direction of the NNW wind.

Table 1. Meteorological data at sampling period

\begin{tabular}{|c|c|c|c|c|c|c|}
\hline $\begin{array}{c}\text { Sample } \\
\text { code }\end{array}$ & $\begin{array}{l}\text { Sampling } \\
\text { term }\end{array}$ & $\begin{array}{c}\text { Sampling } \\
\text { date }\end{array}$ & $\begin{array}{c}\text { Temperature } \\
\left({ }^{\circ} \mathbf{C}\right)\end{array}$ & $\begin{array}{c}\text { Humidity } \\
(\%)\end{array}$ & $\begin{array}{l}\text { Average wind } \\
\text { speed }(\mathbf{k m} / \mathbf{h})\end{array}$ & $\begin{array}{c}\text { Wind } \\
\text { direction }\end{array}$ \\
\hline RW1 & \multirow{3}{*}{ October 2019} & 2.10 .2019 & 9 & 74 & 20 & NNW \\
\hline RW2 & & 9.10 .2019 & 8 & 71 & 21 & NW \\
\hline RW3 & & 22.10 .2019 & 9 & 66 & 20 & NNW \\
\hline RW4 & \multirow{3}{*}{ November 2019} & \begin{tabular}{|l|}
8.11 .2019 \\
\end{tabular} & 8 & 62 & 16 & NNW \\
\hline RW5 & & 22.11 .2019 & 9 & 79 & 21 & ENE \\
\hline RW6 & & 28.11 .2019 & 9 & 86 & 16 & SSW \\
\hline RW7 & \multirow{3}{*}{ December 2019} & 12.12.2019 & 9 & 72 & 12 & SSE \\
\hline RW8 & & \begin{tabular}{|l|}
19.12 .2019 \\
\end{tabular} & 9 & 84 & 20 & NNW \\
\hline RW9 & & 30.12.2019 & 8 & 64 & 8 & NW \\
\hline RW10 & \multirow{5}{*}{ January 2020} & \begin{tabular}{|l|}
9.01 .2020 \\
\end{tabular} & 10 & 60 & 15 & NNW \\
\hline \begin{tabular}{|l|} 
RW11 \\
\end{tabular} & & \begin{tabular}{|l|}
13.01 .2020 \\
\end{tabular} & 9 & 69 & 17 & NNW \\
\hline RW12 & & \begin{tabular}{|l|}
17.01 .2020 \\
\end{tabular} & 10 & 83 & 14 & NW \\
\hline \begin{tabular}{|l|} 
RW13 \\
\end{tabular} & & 23.01 .2020 & 11 & 81 & 18 & ENE \\
\hline \begin{tabular}{|l|} 
RW14 \\
\end{tabular} & & 28.01 .2020 & 7 & 85 & 11 & ESE \\
\hline RW15 & \multirow{5}{*}{ February 2020} & \begin{tabular}{|l|}
3.02 .2020 \\
\end{tabular} & 6 & 62 & 18 & $\mathrm{SE}$ \\
\hline \begin{tabular}{|l|} 
RW16 \\
\end{tabular} & & 10.02 .2020 & 5 & 71 & 17 & WSW \\
\hline \begin{tabular}{|l|} 
RW17 \\
\end{tabular} & & \begin{tabular}{|l|}
18.02 .2020 \\
\end{tabular} & 2 & 51 & 13 & NNW \\
\hline RW18 & & 21.02.2020 & 8 & 86 & 23 & WSW \\
\hline \begin{tabular}{|l|} 
RW19 \\
\end{tabular} & & 24.02 .2020 & 9 & 65 & 17 & NNW \\
\hline \begin{tabular}{|l|} 
RW20 \\
\end{tabular} & \multirow{4}{*}{ March 2020} & \begin{tabular}{|l|}
5.03 .2020 \\
\end{tabular} & 12 & 89 & 12 & WSW \\
\hline \begin{tabular}{|l|} 
RW21 \\
\end{tabular} & & \begin{tabular}{|l|}
10.03 .2020 \\
\end{tabular} & 11 & 85 & 12 & ENE \\
\hline \begin{tabular}{|l|} 
RW22 \\
\end{tabular} & & \begin{tabular}{|l|}
20.03 .2020 \\
\end{tabular} & 5 & 73 & 31 & NNE \\
\hline RW23 & & \begin{tabular}{|l|}
27.03 .2020 \\
\end{tabular} & 14 & 76 & 16 & WS \\
\hline
\end{tabular}

\subsection{Reagents and Chemicals}

All reagents used in the measurements were analytical grade and were purchased from Merck (Germany). The solutions were freshly prepared with ultra-pure distilled water obtained from Milli-Q Plus system (EMD Millipore, Billerica, MA). $\mathrm{pH}$ (4.00 and 7.00 standards) and $\mathrm{KCl}$ solutions were used to calibrate the $\mathrm{pH}$ meter and conductivity meter respectively. For the determination of quantity of organic and inorganic carbon in the samples, organic carbon stock solution was prepared from potassium biphthalate $\left(\mathrm{C}_{8} \mathrm{H}_{5} \mathrm{KO}_{4}\right)$ (Sigma, St. Louis, MO, USA). Inorganic carbon stock solution were composed of anhydrous sodium carbonate $\left(\mathrm{Na}_{2} \mathrm{CO}_{3}\right)$ and anhydrous sodium bicarbonate $\left(\mathrm{NaHCO}_{3}\right)$ (Sigma, St. Louis, MO, USA). In metal analysis, the standards used for the drawing of calibration curves were prepared stock solution of ICP Multi element standard solution XXIV with concentration of $1000 \mathrm{mg} \mathrm{L}^{-1}$ and kept in $1 \% \mathrm{v} / \mathrm{v} \mathrm{HNO}_{3}\left(\mathrm{Merck}_{\text {, }}\right.$ Darmastadt, Germany). Rhodium $\left(50.0 \mu \mathrm{g} \mathrm{L}^{-1}\right)$ was selected as internal standard. Moreover, $\mathrm{HNO}_{3}$ as acidifying reagent was used to preserve samples to $\mathrm{pH}<2$ for heavy metal analysis. The glassware used in the analysis was kept in an acid bath containing $10 \% \mathrm{v} / \mathrm{v} \mathrm{HNO}_{3}-\mathrm{H}_{2} \mathrm{SO}_{4}$ mixture for one day and washed 
with ultra-pure distilled water. For analysis of anions, the preparation of eluent solution was performed from sodium carbonate $\left(\mathrm{Na}_{2} \mathrm{CO}_{3}\right)$ (Merck, Darmstadt, Germany). The studied anions $\left(\mathrm{F}^{-}, \mathrm{Cl}^{-}, \mathrm{SO}_{4}{ }^{2-}, \mathrm{NO}_{3}{ }^{-}\right.$, $\mathrm{NO}_{2}^{-}$) were prepared by dilution of anion standard stock solution (Fluka $1000 \mathrm{mg} / \mathrm{L}$ for IC) (Sigma-Aldrich, St. Louis, MO, USA). In the identification of ammonium $\left(\mathrm{NH}_{4}{ }^{+}\right), \mathrm{NH}_{4} \mathrm{Cl}$ standard solution was prepared by dissolving of anhydrous $\mathrm{NH}_{4} \mathrm{Cl}$ in distilled water and it was supplied from Sigma-Aldrich.

\subsection{Analytical Methods}

Whole studies in this research were realized in the laboratories of The Scientific and Technological Research Council of TURKEY Marmara Research Center (TUBITAK MAM) Environment and Cleaner Production Institute accredited from national (Turkish Accreditation Agency (TURKAK) - since July 16, 2010) and international authorities (German Accreditation Council DAR/DAP (Deutscher Akkreditierung Rat) between December 17, 2002-2010). Moreover, these laboratories have "Measurement and Analysis of Environmental Qualification Certificate" taken from the Republic of Turkey Ministry of Environment and Urbanization on February 21, 2011 to show the ability to measure environmental field matrices.

Standard methods (SMs) [35] were used for the determination of $\mathrm{pH}$ and electrical conductivity (EC), anions $\left(\mathrm{F}^{-}, \mathrm{Cl}^{-}, \mathrm{SO}_{4}{ }^{2-}, \mathrm{NO}_{3}^{-}, \mathrm{NO}_{2}{ }^{-}\right)$, cation $\left(\mathrm{NH}_{4}{ }^{+}\right)$total carbon (TC), total organic carbon (TOC) and total inorganic carbon (TIC). The values of $\mathrm{pH}$ and EC were measured with WTW Inolab multilevel-1 multimeter in accordance with SM 4500-H+ B- (Electrometric Method). Anions were determined with Dionex ICS-1000 Ion chromatography in pursuant to SM $4110 \mathrm{~B}$. Analysis of $\mathrm{NH}_{4}{ }^{+}$was made by Skalar SAN++ continuous flow analyzer according to $\mathrm{SM} 4500-\mathrm{NH}_{3} \mathrm{H}$ (Flow Injection). The concentrations of metals were determined with Perkin Elmer NexION-300X Inductively Coupled Plasma Mass Spectrometer (ICP-MS) in compliance with EPA 6020. $50 \mathrm{~mL}$ sample was acidified with $1 \mathrm{~mL} \mathrm{HNO}_{3}$ maintaining $\mathrm{pH}$ $\sim 2$ and then it was used for metal analysis. The content of mercury $(\mathrm{Hg})$ in the sample was measured by Analytik Jena AG Mercury Analyzer with respect to EN ISO 17852 method. The TOC and TIC measurements were carried out using a Shimadzu TOC-V analyzer (Shimadzu; Kyoto, Japan) according to SM 5310 B.

\subsection{Quality Control of Measurement}

Prior to measurement, all samples were filtrated through a $0.45-\mu \mathrm{m}$ PTFE filter. Quality assurance of $\mathrm{pH}$ and conductivity measurements was successfully provided by obtaining a difference of less than 0.05 for $\mathrm{pH}$ and less than $3 \mu \mathrm{S} / \mathrm{cm}$ for conductivity after the same sample was measured at least 5 times. Trueness of the method for the metals was tested by analysing SPS-SW2-Trace Metals (surface water) certified reference material (CRM) from the UK's National Measurement Institute (NMI-LGC Standards). CRM was treated and analyzed in the same way as rainwater samples. There is a difference within $6 \%-14 \%$ between the results of the elements and the validated values. The relative standard deviations (RSDs) of the anions-cations and TOC were all less than $10 \%$ for reproducibility tests in validation study. The quality control of TOC was routinely carried out using TOC Standard Solution (CRM traceable to SRM from NIST $500 \mathrm{mg} \mathrm{L}^{-1}$ TOC in $\mathrm{H}_{2} \mathrm{O}$ ) supplied by Merck. IC anions standard (ICC-210) purchased from Ultra Scientific as multi component mixture was used to check the quality of anion data.

\section{RESULTS AND DISCUSSIONS}

\section{1. pH and Electrical Conductivity (EC)}

The twenty-three rainwater samples $(\mathrm{N}=23)$ were collected at irregular intervals between October 2019 and March 2020 period, and individual pH values of the samples are shown in Figure 2(a). The pH range in the samples varied between 5.81 and 7.27 and the average $\mathrm{pH}$ value was calculated as 6.51 . The reference value for the evaluation of the $\mathrm{pH}$ of rainwater is 5.60 all over the world. This value shows that unpolluted rainwater is in balance with atmospheric $\mathrm{CO}_{2}[12,33,36,37]$. The high $\mathrm{pH}$ of the samples is neutralization caused by different cations. This situation can be explained by the anthropogenic contribution resulting from intense industrial and vehicle emissions around the sampling point. In accordance with Figure 2(b), none of the samples in this study showed acidic properties. Approximately nine percent $(\sim 9 \%)$ of the $\mathrm{pH}$ 
values were very close to 4.9 to 5.5 , which show slight acidification. More than eighty-two percent (>82\%) of samples ranged from 5.6 to 6.9 , indicating a neutral $\mathrm{pH}$. Approximately nine percent ( $9 \%)$ were found in the range of 6.5-6.9, which shows slightly alkaline [3]. In the light of this information, pH properties of the samples were predominantly neutral during the study.

Similar rainfall studies were performed in other places in Turkey. Muğla (pH 6.90, [38]) and Iskenderun ( $\mathrm{pH} 7.19,[39])$ studies offered higher $\mathrm{pH}$ values when compared to those obtained in this study $(\mathrm{pH}=6.51)$. Istanbul (pH 6.15, [40]), Bolu (pH 6.03, [41]), Ankara (pH 6.10, [42]), Mersin (pH 6.22, [43]), Izmir (pH 5.64, [44]) and Kocaeli (Gebze) (pH 6.30, [45]) also presented acidic rainfall properties than this study due to residential heating, industrial and traffic emissions.


Figure 2. a) Individual $p H$ values and (b) percentage distribution of $p H$ values for rainwater samples

The EC value of rainwater is directly related to the total amount of soluble ions. Thus, lower EC values indicates that the air quality is improved or rainwater has a higher dilution effect [46,47]. Figure 3(a) shows that the EC values of the 23 rainwater samples changed within a range of $22.1 \mu \mathrm{S} \mathrm{cm}^{-1}-126.2 \mu \mathrm{S} \mathrm{cm}^{-1}$. The mean conductivity was $63.0 \mu \mathrm{S} \mathrm{cm}^{-1}$. The EC result is lower than the other rainfall studies such as Petra region $\left(160.6 \mu \mathrm{S} \mathrm{cm}^{-1}\right)$ [24], Ilorin $\left(162.5 \mu \mathrm{S} \mathrm{cm}^{-1}\right)$ [27], Xi'an city $\left(82.8 \mu \mathrm{S} \mathrm{cm}^{-1}\right)$ [48] and higher than that of rainfall study in Mersin region $\left(47.8 \mu \mathrm{S} \mathrm{cm}^{-1}\right)$ [43]. Figure 3(b) demonstrates the dealings between EC value and $\mathrm{Ca}^{2+}$ concentration of samples. It is seen from the graph that there was a good positive correlation $\left(\mathrm{R}^{2}=0.84\right)$ between the two parameters and it can be thought that dust particles, which include a significant amount of calcite and similar type of minerals, act as carriers for soluble solid materials in atmosphere.
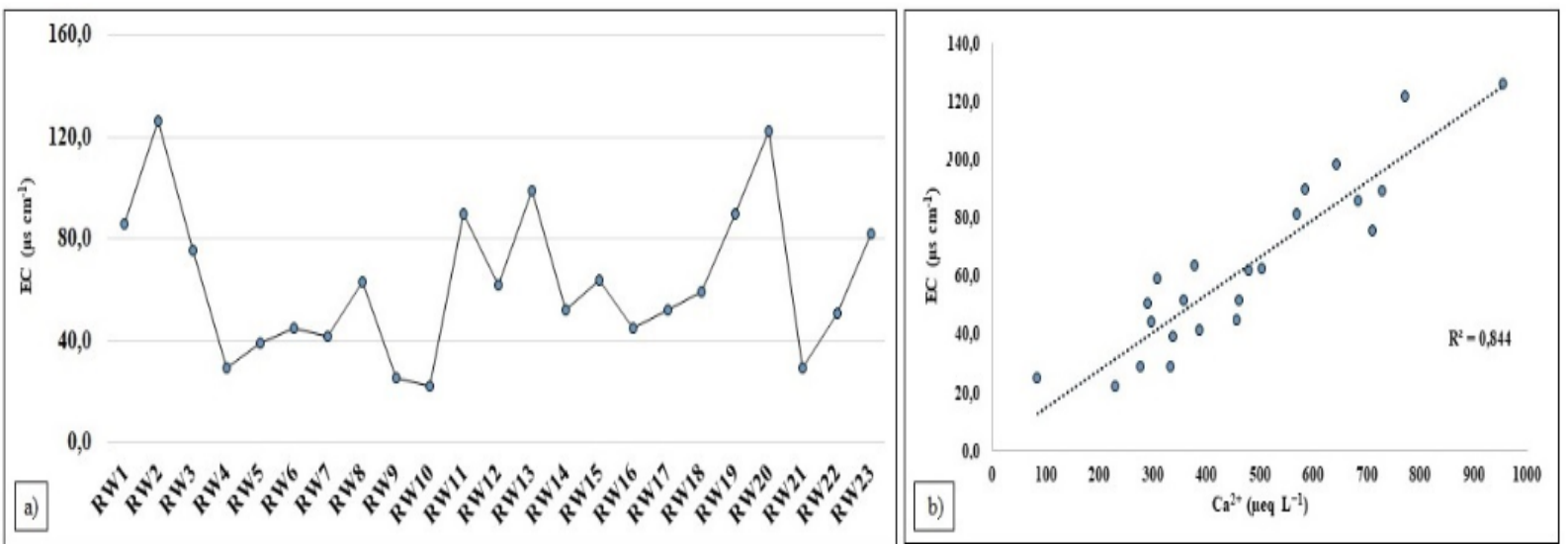

Figure 3. a) EC values of each sample and (b) the relationship between $E C\left(\mu S \mathrm{~cm}^{-1}\right)$ and calcium concentrations $\left(\mu e q L^{-1}\right.$ ) 


\subsection{Ionic Composition}

Ion composition in rainwater samples collected in this study includes $\mathrm{F}^{-}, \mathrm{Cl}^{-}, \mathrm{NO}_{2}{ }^{-}, \mathrm{NO}_{3}^{-}, \mathrm{SO}_{4}{ }^{2-}, \mathrm{PO}_{4}{ }^{3-} \mathrm{Ca}^{2+}$, $\mathrm{K}^{+}, \mathrm{Mg}^{2+}, \mathrm{Na}^{+}$and $\mathrm{NH}_{4}{ }^{+}$ions. The data quality obtained as a result of the measurements was confirmed by ionic balance assessment. In this context, the ion dispersion about the sum of cations divided by the sum of anions (1:1 cations/anions ratio) ( $\left.\mu \mathrm{eq} \mathrm{L}^{-1}\right)$ has been graphically presented in Figure 4. In accordance with the graph, acceptable correlation ( $\mathrm{r}=0.91)$ was obtained from the relationship between the sum of anions and cations as similar result reported by Migliavacca and co-workers (2004) [11]. When the results of ions are analyzed, the sum of cations is two and a half times greater than the sum of anions with a few exceptions as in previous studies $[3,49]$. The difference is thought to be caused by the lack of measurement of organic and other inorganic ions such as bromate $\left(\mathrm{BrO}_{3}^{-}\right)$, carbonate $\left(\mathrm{CO}_{3}{ }^{2-}\right)$, acetate $\left(\mathrm{CH}_{3} \mathrm{COO}^{-}\right)$and formate $\left(\mathrm{HCOO}^{-}\right)$(possibly found in rainwater samples) $[4,17,50]$.

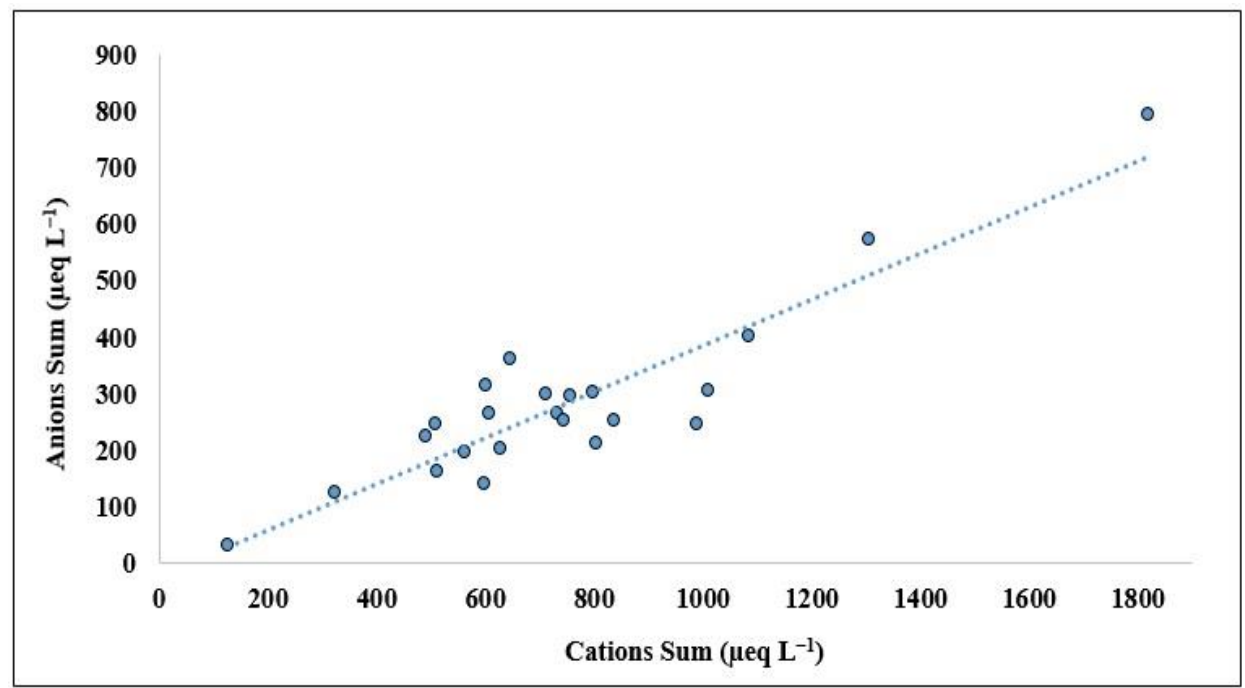

Figure 4. Ionic balance between cations $\left(\mathrm{Ca}^{2+}, \mathrm{K}^{+}, \mathrm{Mg}^{2+}, \mathrm{Na}^{+}\right.$and $\left.\mathrm{NH}_{4}^{+}\right)$and anions $\left(\mathrm{F}^{-}, \mathrm{Cl}, \mathrm{NO}_{2}^{-}, \mathrm{NO}_{3}^{-}\right.$, $\mathrm{SO}_{4}^{2-}$ and $\left.\mathrm{PO}_{4}{ }^{3-}\right)$ in the 23 rainwater samples

In Figure 5, the percentage contribution of each ion species to total ion composition in rainwater in Gebze over the course of six months (autumn, winter and spring seasons) was demonstrated. The ionic sequence is sorted from ascending to descending order: $\mathrm{Ca}^{2+}>\mathrm{Na}^{+}>\mathrm{SO}_{4}{ }^{2-}>\mathrm{Cl}^{-}>\mathrm{Mg}^{2+}>\mathrm{NO}_{3}{ }^{-}>\mathrm{NH}_{4}{ }^{+}>\mathrm{K}^{+}>\mathrm{PO}_{4}{ }^{3-}$ $>\mathrm{NO}_{2}{ }^{-}>\mathrm{F}^{-}$. In accordance with the percentage contribution of ions based volume-weighted mean (VWM) concentrations, $\mathrm{Ca}^{2+}, \mathrm{Na}^{+}$and $\mathrm{SO}_{4}{ }^{2-}$ were the most abundant ions detected in rainwater. These ions contributed approximately $45 \%, 13 \%$ and $11 \%$ of the total ion concentrations analyzed, respectively. These three ions constitute a significant part of the total ion composition with about $70 \%$ (two thirds of the total ionic mass). Similar ions were observed to be dominant in other previous studies about urban or semi-urban areas carried out in Turkey and elsewhere in the world [27,30,43,48,51,52]. It is well known that $\mathrm{Ca}^{2+}, \mathrm{Na}^{+}$ and $\mathrm{Mg}^{2+}$, are the major alkaline species which increase alkalinity, while $\mathrm{SO}_{4}{ }^{2-}, \mathrm{NO}_{3}{ }^{-}$and $\mathrm{Cl}^{-}$are the major acidic species which neutralize alkalinity. Contrary to expectations, $\mathrm{F}^{-}, \mathrm{NO}_{2}{ }^{-}$and $\mathrm{PO}_{4}{ }^{3-}$ was detected in a few samples in small amount, interestingly. The high $\mathrm{Ca}^{2+}$ profile points out construction activities $[3,53]$, agricultural activity $[2,30]$ and various industrial activities producing building materials [27] around the sampling site. Therefore, the transport of $\mathrm{Ca}^{2+}$ ion in precipitation from these sources takes place with the help of suspended dust particles. A work done in Taiwan during the same sampling period, $\mathrm{Ca}^{2+}$ concentration trends are similar, whereas emission sources show differences [54]. 


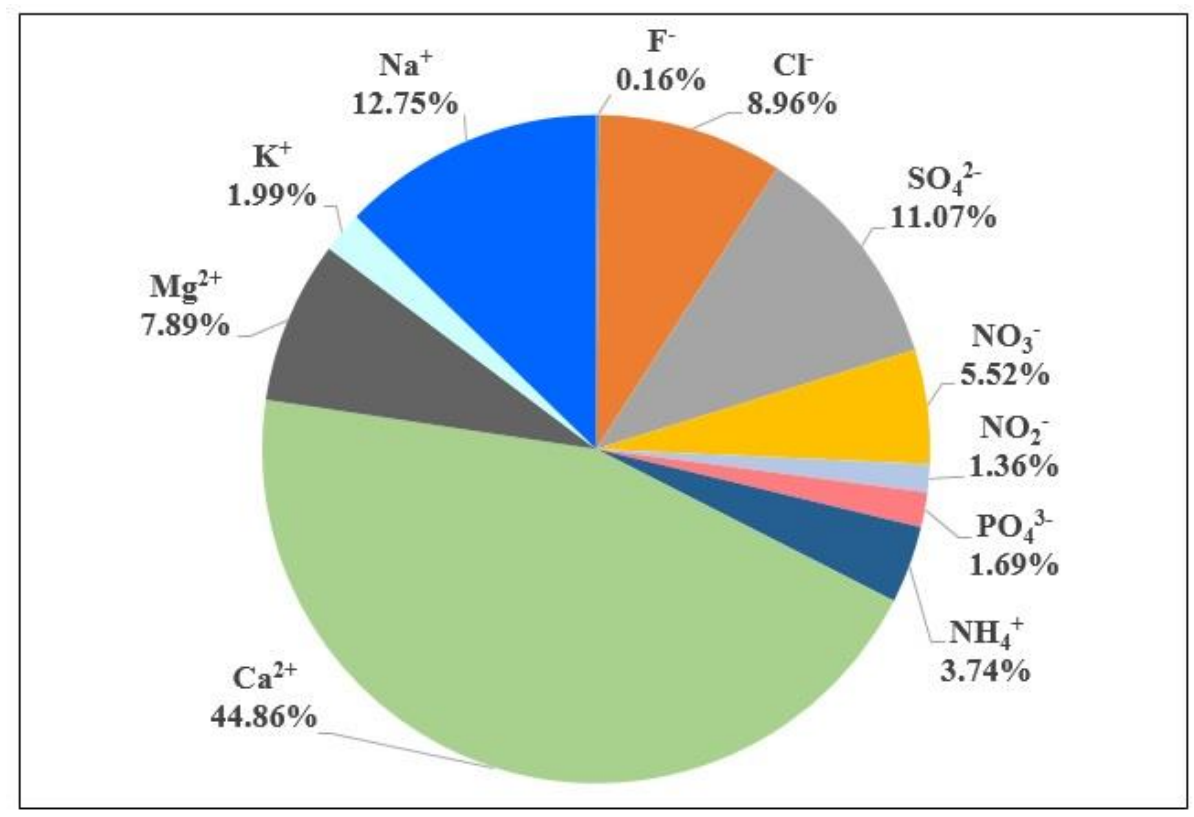

Figure 5. The percentage contribution of each ion species to total ion compositions in rainwater samples (based on VWM values)

The sampling point is very close to the sea in terms of its proximity to the Gulf of Izmit. Besides, there are forest areas and prevalent industrial areas around it. Due to the location of the sampling site (Figure 1), $\mathrm{Na}^{+}$ $(12,75 \%), \mathrm{Cl}^{-}(8.96 \%), \mathrm{Mg}^{2+}(7.89 \%)$ and $\mathrm{K}^{+}(1.99 \%)$ ions may derive mostly from natural sources such as seawater and forest fires [55] and anthropogenic sources such as intense industrial activity and vehicular traffic. Especially, the amounts of $\mathrm{Na}^{+}$and $\mathrm{Cl}^{-}$ion in rainwater can be explained by the presence of sea salt in the terrestrial area close to the sea $[39,56] . \mathrm{SO}_{4}{ }^{2-}(11.07 \%)$ and $\mathrm{NO}_{3}{ }^{-}(5.52 \%)$ anions, which are responsible for the acidic nature of the rainwater with $\mathrm{Cl}^{-}$in this study, accounted for $16.6 \%$ of the total ion concentration. These ions mainly originate from a variety of sources including vehicle emissions, chemical fuel combustion biomass burning, fertilizer use and animal waste [12,57]. $\mathrm{NH}_{4}{ }^{+}$profile, which constitutes only about $4 \%$ of the total ion composition and provides a minor contribution in neutralizing existing acids as well, may arise from a wide variety of biomass burning, soil, livestock manure, animal waste and fertilizer use depend on agricultural activity [3,57].

For the comparison of the data, ion concentrations ( $\mu$ eq $\mathrm{L}^{-1}$ ) based on VWM of the rainwater samples collected in the present study with literature data in Turkey and around the world are given in Table 2. $\mathrm{SO}_{4}{ }^{2-}$ (116.2 $\left.\mu \mathrm{eq} \mathrm{L} \mathrm{L}^{-1}\right), \mathrm{Cl}^{-}\left(94.0 \mu \mathrm{eq} \mathrm{L}{ }^{-1}\right)$ and $\mathrm{NO}_{3}{ }^{-}\left(57.9 \mu \mathrm{eq} \mathrm{L} \mathrm{L}^{-1}\right)$ are the major anions, which cause the increase in rainwater acidity. The contribution of these acidic species in this study pointed out the effects of vehicle emission, coal consumption, cement plants and other industrial sources such as textile and energy production industries around the sampling site, like the study in past performed in similar region of world [33]. The VWM values for $\mathrm{SO}_{4}{ }^{2-}\left(2366.7 \mu \mathrm{eq} \mathrm{L} \mathrm{L}^{-1}\right), \mathrm{Cl}^{-}\left(316.7 \mu \mathrm{eq} \mathrm{L} \mathrm{L}^{-1}\right)$ and $\mathrm{NO}_{3}{ }^{-}\left(68.3 \mu \mathrm{eq} \mathrm{L}{ }^{-1}\right)$ in the study in coastal area of Iran, Mahshahr city [31] are higher than those obtained in this study. There are very limited data about $\mathrm{F}^{-}, \mathrm{NO}_{2}{ }^{-}$and $\mathrm{PO}_{4}{ }^{3-}$ anions in the past studies. In the study conducted in Guangzhou city, China between 2016 and 2017 [57], the $\mathrm{PO}_{4}{ }^{3-}$ concentration is almost twice that of this study, the $\mathrm{NO}_{2}{ }^{-}$ concentration is almost one third of this study and the $\mathrm{F}^{-}$concentration is very close to this study. In addition, similar results were obtained with the study [58] in New Jersey, one of the smallest states in the USA, regarding $\mathrm{F}^{-}$concentration. With a few exceptions, the concentrations of each cation $\left(\mathrm{NH}_{4}{ }^{+}, \mathrm{Ca}^{2+}\right.$, $\mathrm{Mg}^{2+}, \mathrm{K}^{+}$and $\mathrm{Na}^{+}$) in this study are much higher than the concentrations reported in other cities given in Table 2 . 
Table 2. Comparison of concentrations $\left(\mu e q L^{-1}\right)$ of ions in Gebze rainfall study with literature data in Turkey and around the world

\begin{tabular}{|c|c|c|c|c|c|c|c|c|c|c|c|c|c|c|}
\hline \multicolumn{2}{|c|}{ Constituent } & Period & $\mathbf{F}^{-}$ & $\mathrm{Cl}^{-}$ & $\mathrm{SO}_{4}^{2-}$ & $\mathrm{NO}_{3}^{-}$ & $\mathrm{NO}_{2}^{-}$ & $\mathrm{PO}_{4}{ }^{3-}$ & $\mathrm{NH}_{4}{ }^{+}$ & $\mathbf{C a}^{2+}$ & $\mathrm{Mg}^{2+}$ & $\mathbf{K}^{+}$ & $\mathrm{Na}^{+}$ & Ref. \\
\hline \multirow{3}{*}{$\begin{array}{l}\text { Gebze } \\
*\end{array}$} & Range & \multirow{3}{*}{$2019-2020$} & $\begin{array}{c}<1.0 \\
- \\
1.6 \\
\end{array}$ & $\begin{array}{c}7.1 \\
- \\
427.1 \\
\end{array}$ & $\begin{array}{c}5.5 \\
- \\
220.1 \\
\end{array}$ & $\begin{array}{c}15.8 \\
- \\
137.9 \\
\end{array}$ & $\begin{array}{c}<2.0 \\
- \\
27.0 \\
\end{array}$ & $\begin{array}{c}<16.0 \\
- \\
17.7 \\
\end{array}$ & $\begin{array}{c}6.9 \\
- \\
107.6 \\
\end{array}$ & $\begin{array}{c}84.7 \\
- \\
952.3 \\
\end{array}$ & $\begin{array}{c}18.1 \\
- \\
279.5 \\
\end{array}$ & $\begin{array}{c}3.9 \\
- \\
55.0 \\
\end{array}$ & $\begin{array}{c}7.0 \\
- \\
445.1 \\
\end{array}$ & \multirow{3}{*}{$\begin{array}{l}\text { This } \\
\text { Stud }\end{array}$} \\
\hline & Mean & & 1.6 & 94.0 & 116.2 & 57.9 & 14.3 & 17.7 & 39.2 & 470.6 & 82.8 & 20.9 & 133.8 & \\
\hline & SD & & - & 92.6 & 51.7 & 29.4 & 7.1 & - & 27.1 & 207.3 & 68.0 & 13.2 & 125.5 & \\
\hline \multicolumn{2}{|c|}{ Limeira } & 2013-2014 & NA & 7.1 & 15.5 & 14.7 & NA & NA & 34.4 & 54.9 & 17.4 & 5.7 & 22.4 & [3] \\
\hline \multicolumn{2}{|c|}{ Guangzhou } & 2016-2017 & 1.0 & 34.3 & 32.7 & 24.2 & 4.8 & 30.0 & 21.6 & 21.1 & 7.4 & 17.2 & 7.6 & [57] \\
\hline \multicolumn{2}{|c|}{ Mahshahr } & 2015 & NA & 316.7 & 2366.7 & 68.3 & NA & NA & 26.5 & 875.0 & 758.3 & 18.3 & 18.3 & [31] \\
\hline \multicolumn{2}{|c|}{ Juiz de Fora } & 2014 & $\mathrm{NA}$ & 18.3 & 3.0 & 25.6 & NA & NA & NA & 31.9 & 13.8 & 16.0 & 29.1 & [30] \\
\hline \multicolumn{2}{|c|}{ Kolkata } & 2013-2015 & NA & 39.6 & 87.6 & 24.5 & NA & NA & 37.2 & 116.5 & 16.8 & 14.2 & 54.3 & [29] \\
\hline \multicolumn{2}{|c|}{ Bathurst } & 2017-2018 & NA & 23.0 & 65.0 & 8.0 & NA & NA & NA & 23.0 & 12.0 & 14.0 & 44.0 & [59] \\
\hline \multicolumn{2}{|c|}{ A Coruña } & 2011-2012 & NA & 180.6 & 72.5 & 31.5 & NA & NA & 32.5 & 121.7 & 53.7 & 15.1 & 188.2 & [14] \\
\hline \multicolumn{2}{|l|}{ Petra } & 2002-2004 & NA & 80.6 & 53.2 & 35.7 & NA & NA & 26.3 & 163.1 & 62.3 & 18.4 & 75.6 & [24] \\
\hline \multicolumn{2}{|c|}{ New Jersey } & 2006-2007 & 1.1 & 10.7 & 38.1 & 14.4 & NA & NA & 24.4 & 6.0 & 3.3 & 1.3 & 10.9 & [58] \\
\hline \multicolumn{2}{|c|}{ Thessaloniki } & $1989-1990$ & NA & 50.1 & 194.0 & 49.7 & NA & NA & 73.2 & 254.0 & 22.9 & 12.2 & 34.0 & {$[60]$} \\
\hline \multicolumn{2}{|l|}{ Muğla } & 2002 & NA & NA & 124.0 & 23.0 & NA & NA & 30.0 & 174.0 & NA & 3.5 & 17.0 & [38] \\
\hline \multicolumn{2}{|c|}{ Ankara } & 1994-1996 & NA & 20.4 & 48.0 & 29.2 & NA & NA & 86.4 & 71.4 & 9.3 & 9.8 & 15.6 & {$[61]$} \\
\hline
\end{tabular}

NA: not available

Ref.: reference

SD: standard deviation

\subsection{Trace Elements}

The data about the measurement limit values (LOD, LOQ and RSD) of ICP-MS (for trace elements), TOC analyzer (for TOC, TC and TIC) and seasonal concentration variations of trace elements in rainwater at Gebze are shown in Table 3. Trace elements $\left(\mu \mathrm{g} \mathrm{L}^{-1}\right)$ and TOC, TC, TIC $\left(\mathrm{mg} \mathrm{L}^{-1}\right)$ measurements of the samples collected on the dates specified in Table 1 were carried out to the related instruments. The concentrations for autumn, winter and spring seasons were determined by calculating the mean values obtained as a result of the measurements for each parameter. The trend of trace elements based on concentrations during the whole study period was: $\mathrm{Al}\left(34.52 \mu \mathrm{g} \mathrm{L}^{-1}\right)>\mathrm{Fe}\left(26.03 \mu \mathrm{g} \mathrm{L}^{-1}\right)>\mathrm{Ba}\left(20.67 \mu \mathrm{g} \mathrm{L}^{-}\right.$ $\left.{ }^{1}\right)>\operatorname{Mn}\left(18.06 \mu \mathrm{g} \mathrm{L}^{-1}\right)>\mathrm{B}\left(16.39 \mu \mathrm{g} \mathrm{L}^{-1}\right)>\mathrm{Sr}\left(16.27 \mu \mathrm{g} \mathrm{L}^{-1}\right)>\mathrm{Cu}\left(10.42 \mu \mathrm{g} \mathrm{L}^{-1}\right)$, respectively. The amount of these elements consisted of $84 \%$ to the sum of the amount of all ions measured within the scope of the study. The concentrations of trace elements at spring season (partially dry season) were higher than those at autumn and winter seasons (wet seasons) with a few exceptions like B, Fe, Mo and Rb. Especially, the concentration of $\mathrm{Cu}$ in spring period was excessively higher than those in autumn and Winter periods. Izmit Gulf is an important region where the metallurgy and steel industries operate extensively. $\mathrm{Al}$ and $\mathrm{Fe}$ elements, which are defined as crustal elements, are soil based elements found in the Earth's crust. Their high concentrations were expected situation since there were new highway constructions (connection roads of newly built Osman Gazi and Yavuz Sultan Selim Bridges) around the sampling point. The concentrations of these elements were presented high in both aerosols and precipitation samples of Iskenderun study [39] collected at the College Campus station as in this study. 
Table 3. The measurement limit values ( $L O D, L O Q$ and RSD) of instrument and seasonal concentrations of trace elements in rainwater at Gebze, (trace elements in $\mu g L^{-1}$ and TOC, TC, TIC in $m g L^{-1}$ )

\begin{tabular}{|l|c|c|c|c|c|c|c|c|c|c|}
\hline Elements & LOD & LOQ & $\begin{array}{c}\text { RSD } \\
(\boldsymbol{\%})\end{array}$ & $\begin{array}{c}\text { Autumn 2019 } \\
\mathbf{( N = 6 )}\end{array}$ & $\begin{array}{c}\text { Winter } \\
\mathbf{2 0 2 0}(\mathbf{N = 1 3})\end{array}$ & $\begin{array}{c}\text { Spring 2020 } \\
(\mathbf{N = 4})\end{array}$ & SD & Mean & Min & Max \\
\hline $\mathrm{Al}$ & 0.007 & 0.021 & 21.4 & 32.93 & 28.63 & 57.61 & 15.64 & 34.52 & 1.98 & 78.41 \\
\hline $\mathrm{As}$ & 0.133 & 0.432 & 7.5 & 0.39 & 0.39 & 0.88 & 0.28 & 0.49 & 0.21 & 0.99 \\
\hline $\mathrm{B}$ & 0.015 & 0.048 & 13.5 & 22.41 & 13.04 & 16.20 & 4.77 & 16.39 & 2.89 & 58.02 \\
\hline $\mathrm{Ba}$ & 0.025 & 0.067 & 7.2 & 15.26 & 16.49 & 38.50 & 13.08 & 20.67 & 2.64 & 44.17 \\
\hline $\mathrm{Cd}$ & 0.092 & 0.274 & 8.3 & 0.13 & 0.11 & 0.24 & 0.07 & 0.14 & 0.04 & 0.30 \\
\hline $\mathrm{Co}$ & 0.002 & 0.008 & 9.6 & 0.24 & 0.28 & 0.47 & 0.12 & 0.31 & 0.04 & 0.67 \\
\hline $\mathrm{Cr}$ & 0.008 & 0.026 & 10.2 & 0.86 & 1.19 & 3.05 & 1.18 & 1.50 & 0.17 & 4.27 \\
\hline $\mathrm{Cu}$ & 0.065 & 0.200 & 13.1 & 6.86 & 8.34 & 19.79 & 7.08 & 10.42 & 2.85 & 24.79 \\
\hline $\mathrm{Fe}$ & 0.216 & 1.040 & 5.9 & 14.24 & 32.25 & 28.28 & 9.46 & 26.03 & 2.79 & 97.54 \\
\hline $\mathrm{Li}$ & 0.857 & 2.470 & 7.4 & 0.43 & 0.27 & 0.68 & 0.20 & 0.40 & 0.03 & 1.27 \\
\hline $\mathrm{Mn}$ & 0.029 & 0.084 & 14.8 & 11.28 & 19.71 & 23.99 & 6.47 & 18.06 & 2.89 & 56.36 \\
\hline $\mathrm{Mo}$ & 0.037 & 0.099 & 10.5 & 0.51 & 0.22 & 0.24 & 0.16 & 0.30 & 0.11 & 0.79 \\
\hline $\mathrm{Ni}$ & 0.021 & 0.056 & 7.6 & 1.77 & 1.53 & 2.92 & 0.75 & 1.86 & 0.42 & 3.40 \\
\hline $\mathrm{Pb}$ & 0.021 & 0.073 & 14.7 & 0.36 & 1.49 & 4.09 & 1.91 & 1.73 & 0.09 & 6.72 \\
\hline $\mathrm{Rb}$ & 0.011 & 0.035 & 13.2 & 1.13 & 0.40 & 0.84 & 0.37 & 0.68 & 0.13 & 1.87 \\
\hline $\mathrm{Sb}$ & 0.078 & 0.210 & 11.4 & 0.30 & 0.28 & 0.63 & 0.20 & 0.36 & 0.14 & 0.80 \\
\hline $\mathrm{Se}$ & 0.003 & 0.007 & 3.9 & 0.19 & 0.17 & 0.23 & 0.03 & 0.18 & 0.06 & 0.42 \\
\hline $\mathrm{Sn}$ & 0.116 & 0.329 & 13.7 & 0.15 & 0.27 & 0.22 & 0.06 & 0.24 & 0.10 & 0.64 \\
\hline $\mathrm{Sr}$ & 0.034 & 0.057 & 4.5 & 30.20 & 10.82 & 11.45 & 11.01 & 16.27 & 2.31 & 62.77 \\
\hline $\mathrm{Ti}$ & 0.022 & 0.062 & 7.4 & 1.78 & 3.71 & 2.58 & 0.97 & 3.19 & 0.84 & 8.85 \\
\hline $\mathrm{V}$ & 0.023 & 0.044 & 5.4 & 0.79 & 0.57 & 1.41 & 0.44 & 0.80 & 0.23 & 1.66 \\
\hline $\mathrm{Zn}$ & 0.001 & 0.004 & 13.2 & 2.74 & 1.18 & 0.29 & 1.24 & 1.41 & 0.01 & 5.56 \\
\hline $\mathrm{Hg}$ & 0.012 & 0.034 & 10.1 & 2.70 & 3.51 & 4.11 & 0.71 & 3.49 & 1.65 & 5.60 \\
\hline $\mathrm{TC}$ & 0.10 & 0.50 & 6.7 & 4.66 & 3.29 & 4.72 & 0.81 & 3.93 & 0.45 & 7.25 \\
\hline $\mathrm{TOC}$ & 0.10 & 0.50 & 4.5 & 1.78 & 1.07 & 1.71 & 0.39 & 1.38 & 0.18 & 3.03 \\
\hline $\mathrm{TIC}$ & 0.10 & 0.50 & 4.5 & 2.89 & 2.21 & 3.02 & 0.43 & 2.54 & 0.27 & 4.27 \\
\hline & & & & & & & & & & \\
\hline
\end{tabular}

Table 4 presents the comparison of average concentrations of trace elements and TOC, TC, TIC parameters between the data of rainwater collected at Gebze and studies in rural and urban areas of other countries. In accordance with Table 4, the concentrations of all parameters in this study were determined lower than those in India and Brazil when they were investigated together on the basis of the parameters measured in the related studies. Concentrations of $\mathrm{Al}, \mathrm{Co}$ and $\mathrm{Cd}$ in the rainwater samples in Gebze were lower than in other countries. $\mathrm{Zn}, \mathrm{Mn}, \mathrm{Fe}$ and $\mathrm{Cu}$ concentrations of rainwater in this study exceed those in Turkey (Iskenderun), which the samples collected at the College Campus station. Except $\mathrm{Cu}$, other trace elements measured in Turkey (Antalya) study were significantly higher than this study. Ni and Pb concentrations in rainwater of this study area is slightly higher than the study in Spain, but lower than the studies in India, Brazil, Turkey and Jordan. $\mathrm{Cr}, \mathrm{Zn}, \mathrm{Fe}$ and $\mathrm{Cu}$ concentrations of rainwater in this study much higher those in Spain and Turkey (Ankara). There is a limited number of data from past studies on $\mathrm{Ba}, \mathrm{Li}, \mathrm{Sb}, \mathrm{Sr}, \mathrm{V}, \mathrm{TC}$, TOC and TIC parameters $[14,39,62]$. Therefore, it is not possible to make a healthy comparison between countries about these parameters. However, a general statement can be said in the light of the available data. Except for $\mathrm{Ba}$ and $\mathrm{Sb}$, the values of the other parameters in this study are lower than other countries. 
Table 4. The comparison of trace elements between the data of rainwater collected at Gebze and literature data reported for other countries (trace elements in $\mu g L^{-1}$ and TOC, TC, TIC in $\mathrm{mg} \mathrm{L}^{-1}$ )

\begin{tabular}{|l|c|c|c|c|c|c|c|c|}
\hline Elements & This study & India & Brazil & Spain & $\begin{array}{c}\text { Turkey } \\
\text { (Iskenderun) }\end{array}$ & $\begin{array}{c}\text { Turkey } \\
\text { (Antalya) }\end{array}$ & $\begin{array}{c}\text { Turkey } \\
\text { (Ankara) }\end{array}$ & Jordan \\
\hline Period & $2019-2020$ & $2016-2017$ & 2014 & $2011-2012$ & 2000 & $1992-1994$ & $1992-1994$ & $1998-2000$ \\
\hline Ref. & - & {$[33]$} & {$[30]$} & {$[14]$} & {$[39]$} & {$[62]$} & {$[42]$} & {$[63]$} \\
\hline $\mathrm{Al}$ & 34.52 & NA & NA & 49.4 & 35.97 & 580 & 47 & 382 \\
\hline $\mathrm{Ba}$ & 20.67 & NA & NA & 15.2 & 19.55 & NA & NA & NA \\
\hline $\mathrm{Cd}$ & 0.14 & NA & 0.17 & NA & 1.63 & 4.5 & 8.6 & 0.42 \\
\hline $\mathrm{Co}$ & 0.31 & $40-200$ & NA & 5.0 & 3.44 & NA & NA & NA \\
\hline $\mathrm{Cr}$ & 1.50 & $27-193$ & NA & 0.28 & 3.27 & 9 & 0.38 & 0.77 \\
\hline $\mathrm{Cu}$ & 10.42 & $20-240$ & 89.9 & 2.1 & 5.28 & 4.9 & 3.7 & 3.08 \\
\hline $\mathrm{Fe}$ & 26.03 & $26-429$ & NA & 11.4 & 18.06 & 531 & 31 & 92 \\
\hline $\mathrm{Li}$ & 0.40 & NA & NA & NA & 0.82 & NA & NA & NA \\
\hline $\mathrm{Mn}$ & 18.06 & $46-834$ & 49.7 & 6.4 & 3.87 & NA & NA & NA \\
\hline $\mathrm{Ni}$ & 1.86 & $24-730$ & NA & 1.0 & 6.62 & 24 & 2.2 & 2.62 \\
\hline $\mathrm{Pb}$ & 1.73 & $41-677$ & 11.8 & 0.51 & 5.22 & 10 & 3.3 & 2.57 \\
\hline $\mathrm{Sb}$ & 0.36 & NA & NA & NA & NA & NA & NA & 0.16 \\
\hline $\mathrm{Sr}$ & 16.27 & $69-464$ & NA & 5.5 & NA & NA & NA & NA \\
\hline $\mathrm{V}$ & 0.80 & NA & NA & 0.83 & NA & NA & NA & 4.21 \\
\hline $\mathrm{Zn}$ & 1.41 & $153-809$ & NA & 55.7 & 0.99 & 137 & 0.02 & 6.52 \\
\hline $\mathrm{TC}$ & 3.93 & NA & NA & 17.2 & NA & NA & NA & NA \\
\hline $\mathrm{TOC}$ & 1.38 & $2.7-8.85$ & NA & 15.3 & NA & NA & NA & NA \\
\hline $\mathrm{TIC}$ & 2.54 & NA & NA & 0.38 & NA & NA & NA & NA \\
\hline $\mathrm{NA}:$ not available & & & & & & & & \\
\hline
\end{tabular}

\subsection{Enrichment Factor Analysis}

The Enrichment Factor (EF) makes an important contribution in understanding of whether the ions in rainwater are of marine or continental origin. For this reason, $\mathrm{Na}^{+}$is often preferred as the best reference trace element for marine emission source [37,64], while $\mathrm{Ca}^{2+}$ is utilized as the best reference trace element for continental emissions or terrestrial crusts $[47,65]$.

In this study, $\mathrm{Ca}^{2+}$ for the determination of crust sources (Equation (1)) and $\mathrm{Na}^{+}$for the estimation of marine sources (Equation (2)) [3,47] were used as reference elements in the calculation of EF values:

$E F_{\text {soil }}=\frac{\left(X / C a^{2+}\right)_{\text {rainwater }}}{\left(X / C a^{2+}\right)_{\text {soil }}}$

$E F_{\text {seawater }}=\frac{\left(X / N a^{+}\right)_{\text {rainwater }}}{\left(X / N a^{+}\right)_{\text {seawater }}}$

where $\left(\mathrm{X} / \mathrm{Ca}^{2+}\right)_{\text {rainwater }}$ is computed from the concentration of the ion of interest $\left(\mathrm{NO}_{3}{ }^{-}, \mathrm{Cl}^{-}, \mathrm{SO}_{4}{ }^{2-}, \mathrm{Na}^{+}, \mathrm{Mg}^{2+}\right.$ and $\left.\mathrm{K}^{+}\right)$and the $\mathrm{Ca}^{2+}$ concentration measured in the rainwater samples. $\left(\mathrm{X} / \mathrm{Ca}^{2+}\right)_{\text {soil }}$ is the ratio from crustal composition, obtained from $[3,66] .\left(\mathrm{X} / \mathrm{Na}^{+}\right)_{\text {rainwater }}$ is calculated from the concentration of the ion of interest $\left(\mathrm{Cl}^{-}, \mathrm{SO}_{4}{ }^{2-}, \mathrm{K}^{+}, \mathrm{Mg}^{2+}\right.$ and $\left.\mathrm{Ca}^{2+}\right)$ and the $\mathrm{Na}^{+}$concentration determined in the rainwater samples. $\left(\mathrm{X} / \mathrm{Na}^{+}\right)_{\text {seawater }}$ is the proportion of material from sea, acquired from $[3,48,64]$. Because marine contributions of $\mathrm{NH}_{4}{ }^{+}, \mathrm{NO}_{3}{ }^{-}, \mathrm{PO}_{4}{ }^{3-}$ and $\mathrm{F}^{-}$are insufficient [65], they were not included in the calculations.

Table 5 presents the EF values of ions in rainwater and the comparison of seawater and soil ratios with rainwater constituents. The obtained EF values in the study can be evaluated for the influence of Earth's 
crust in accordance with the studies of Poissant and Zhang [47,67] as follows: (a) if $\mathrm{EF}_{\text {soil }}$ value is obtained above 1; the influence from Earth's crust is high or the intensity of ions is enhanced from the related source; (b) if $\mathrm{EF}_{\text {soil }}$ value is obtained below 1, the dilution of ions is performed in the reference source. Also, the

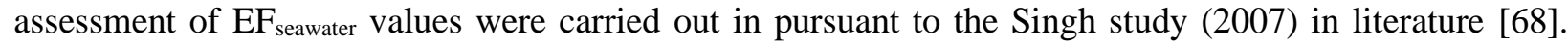
$\mathrm{EF}_{\text {seawater }}$ value greater than 1 is defined as the enrichment of ions from non-marine sources and $\mathrm{EF}_{\text {seawater }}$ value lower than or equal to 1 is expressed as the contribution only from marine environment.

The $\mathrm{EF}_{\text {soil }}$ values of $\mathrm{Cl}^{-}, \mathrm{SO}_{4}{ }^{2-}$ and $\mathrm{NO}_{3}{ }^{-}$were obtained $66.69,79.62$ and 61.55 , respectively. The high enrichment factors demonstrate that these ions are heavily influenced by Earth crust source and the other anthropogenic sources such as biomass production from agricultural activities and emissions from intense local and intercity traffic around the sampling point. The $\mathrm{EF}_{\text {soil }}$ values of $\mathrm{Na}^{+}(0.50), \mathrm{Mg}^{2+}(0.31)$ and $\mathrm{Ca}^{2+}$ (0.07) have been found to be lower than 1, showing in Table 5. These results indicate that these ions are

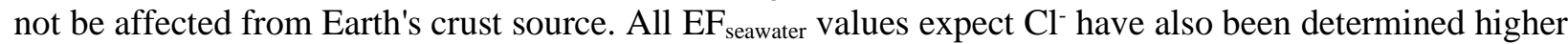

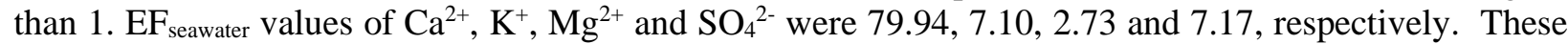
high enrichment factors emphasize that the contributions were from local sources other than marine sources. The $\mathrm{EF}_{\text {seawater }}$ and $\mathrm{EF}_{\text {soil }}$ values for $\mathrm{SO}_{4}{ }^{2-}$ mean that its enrichment mostly derives from Earth crust source and partly from marine source. For $\mathrm{Mg}^{2+}$ and $\mathrm{K}^{+}$ions, it cannot be said clearly whether the enrichment source is from marine or Earth crust source by the time $\mathrm{EF}_{\text {seawater }}$ and $\mathrm{EF}_{\text {soil }}$ values are assessed all together. The contributions are from other anthropogenic sources. When the results of EF in this study are compared with locations conducted in the previous studies $[3,47,48]$, the results appear to be similar and compatible.

Table 5. The comparison of seawater and soil ratios with rainwater constituents

\begin{tabular}{|c|c|c|c|c|c|c|}
\hline & $\mathrm{Na}^{+} / \mathrm{Ca}^{2+}$ & $\mathrm{Mg}^{2+} / \mathrm{Ca}^{2+}$ & $\mathrm{K}^{+} / \mathrm{Ca}^{2+}$ & $\mathrm{Cl}^{-} / \mathrm{Ca}^{2+}$ & $\mathrm{SO}_{4}{ }^{2-} / \mathrm{Ca}^{2+}$ & $\mathrm{NO}_{3}{ }^{-} / \mathrm{Ca}^{2+}$ \\
\hline Rainwater ratio & 0.284 & 0.176 & 0.044 & 0.200 & 0.247 & 0.123 \\
\hline Soil ratio & 0.569 & 0.561 & 0.610 & 0.003 & 0.0031 & 0.002 \\
\hline \multirow[t]{2}{*}{$\mathrm{EF}_{\text {soil }}$} & 0.50 & 0.31 & 0.07 & 66.59 & 79.62 & 61.55 \\
\hline & $\mathrm{Ca}^{2+} / \mathrm{Na}^{+}$ & $\mathrm{Mg}^{2+} / \mathrm{Na}^{+}$ & $\mathbf{K}^{+} / \mathrm{Na}^{+}$ & $\mathrm{Cl}^{-} / \mathrm{Na}^{+}$ & $\mathrm{SO}_{4}{ }^{2-} / \mathrm{Na}^{+}$ & \\
\hline Rainwater ratio & 3.517 & 0.619 & 0,156 & 0.703 & 0.868 & \\
\hline Seawater ratio & 0.044 & 0.227 & 0,022 & 1.16 & 0.121 & \\
\hline $\mathrm{EF}_{\text {seawater }}$ & 79.94 & 2.73 & 7.10 & 0.61 & 7.17 & \\
\hline
\end{tabular}

\subsection{Natural and Anthropogenic Sources}

Rainwater receives its components from the atmosphere through natural or anthropogenic sources. It was thought that natural ones are emissions of crust fraction (\% CF in Equation (3)) and sea fraction \%SF in Equation (4)). It is conceived that the remaining percentage of these two values is the anthropogenic source fraction (\% ASF) for different ion types [47]

$\% C F=\frac{100 *\left(X / C a^{2+}\right)_{\text {soil ratio }}}{\left(X / C a^{2+}\right)_{\text {rainwater ratio }}}$

$\% S F=\frac{100 *\left(X / N a^{+}\right)_{\text {seawater ratio }}}{\left(X / N a^{+}\right)_{\text {rainwater ratio }}}$. 
Table 6. Contribution of source

\begin{tabular}{|c|c|c|c|}
\hline \multirow{2}{*}{ Ion } & \multirow{2}{*}{$\begin{array}{c}\text { Sea Salt Fraction } \\
(\% \mathbf{S F})\end{array}$} & $\begin{array}{c}|c| \\
\text { Crust fraction } \\
(\boldsymbol{\%} \mathbf{C F})\end{array}$ & $\begin{array}{c}\text { Anthropogenic source fraction } \\
(\% \mathbf{H S F})\end{array}$ \\
\cline { 3 - 4 } & 1.25 & 98.75 & - \\
\hline $\mathrm{Ca}^{2+}$ & 36.69 & - & 63.31 \\
\hline $\mathrm{Mg}^{2+}$ & 14.08 & - & 85.92 \\
\hline $\mathrm{K}^{+}$ & - & 1.50 & 98.50 \\
\hline $\mathrm{Cl}^{-}$ & 13.94 & 1.26 & 84.81 \\
\hline $\mathrm{SO}_{4}{ }^{2-}$ & - & 1.62 & 98.38 \\
\hline $\mathrm{NO}_{3}^{-}$ & & & \\
\hline
\end{tabular}

Table 6 shows the values obtained for natural and anthropogenic fractions as a result of calculations. \%CF values demonstrated that $\mathrm{NO}_{3}{ }^{-}(98.38 \%)$ (The sea fraction for this ion has not been considered to be quite low), $\mathrm{SO}_{4}{ }^{2-}(84.81 \%), \mathrm{Cl}^{-}(98.50 \%), \mathrm{K}^{+}(85.92 \%)$ and $\mathrm{Mg}^{2+}(63.31 \%)$ possessed a huge amount of contribution from different anthropogenic sources. $\% \mathrm{SF}$ value of $\mathrm{Mg}^{2+}(36.69 \%)$ indicated that rainwater also contributes significantly to the sea fraction. Almost all $\mathrm{Ca}^{2+}$ ions $(98.75 \%)$ were caused by crust fractions $(\% \mathrm{CF})$.

\section{CONCLUSIONS}

In this study, the chemical composition of the rainwater collected in Gebze, which is one of the most important industrial activity zones in the coastal district of Turkey, during the period from October 2019 to March 2020. The chemical compositions of the rainwater samples were described in terms of ions $\left(\mathrm{F}^{-}, \mathrm{Cl}^{-}\right.$, $\mathrm{NO}_{2}{ }^{-}, \mathrm{NO}_{3}{ }^{-}, \mathrm{SO}_{4}{ }^{2-}, \mathrm{PO}_{4}{ }^{3-} \mathrm{Ca}^{2+}, \mathrm{K}^{+}, \mathrm{Mg}^{2+}, \mathrm{Na}^{+}$and $\mathrm{NH}_{4}^{+}$) and twenty-three elements. Parameters such as $\mathrm{pH}$, conductivity and TOC, TIC, TC were also evaluated. The mean concentrations of ions and trace elements of the rainwater samples collected in the present study were compared with those concentrations in previous studies of Turkey and around the world.

The following findings were obtained as a result of this study:

- The $\mathrm{pH}$ range in the samples varied between 5.81 and 7.27 (average $\mathrm{pH}: 6.51$ ). More than eightytwo percent (>82\%) of samples ranged from 5.6 to 6.9 , indicating a neutral $\mathrm{pH}$. The reference value for the evaluation of the $\mathrm{pH}$ of rainwater is 5.60 , which this value indicates that unpolluted rainwater is in balance with atmospheric $\mathrm{CO}_{2}[12,33,36,37]$, all over the world. Thus, $\mathrm{pH}$ of the samples was predominantly neutral during the study.

- The EC values of the 23 rainwater samples changed within a range of $22.1 \mu \mathrm{S} \mathrm{cm}^{-1}-126.2 \mu \mathrm{S} \mathrm{cm}^{-1}$ (average EC: $63.0 \mu \mathrm{S} \mathrm{cm}^{-1}$ ).

- Relationship between EC values and $\mathrm{Ca}^{2+}$ concentrations of samples has been thought that dust particles, which include a significant amount of calcite and similar type of minerals, act as carriers for soluble solid materials in atmosphere.

- The most abundant ions were $\mathrm{Ca}^{2+}(45 \%), \mathrm{Na}^{+}(13 \%)$ and $\mathrm{SO}_{4}{ }^{2-}(11 \%)$ in terms of the order of percentage contribution of ion species to total ion composition in rainwater

- High $\mathrm{Ca}^{2+}$ profile refers to the construction activities, agricultural activity and various industrial activities producing building materials around the sampling site.

- $\mathrm{SO}_{4}{ }^{2-}$ and $\mathrm{NO}_{3}{ }^{-}$anions accounted for $16.6 \%$ of the total ion concentration mainly originate from a variety of sources including vehicle emissions, chemical fuel combustion biomass burning, fertilizer use and animal waste [12,57].

- $\mathrm{Na}^{+}(13 \%), \mathrm{Cl}^{-}(9 \%), \mathrm{Mg}^{2+}(8 \%)$ and $\mathrm{K}^{+}(2 \%)$ ions may derive mostly from natural sources such as seawater and anthropogenic sources such as intense industrial activity and vehicular traffic. 
- The concentrations of $\mathrm{Al}\left(34.52 \mu \mathrm{g} \mathrm{L}^{-1}\right), \mathrm{Fe}\left(26.03 \mu \mathrm{g} \mathrm{L}^{-1}\right), \mathrm{Ba}\left(20.67 \mu \mathrm{g} \mathrm{L}^{-1}\right), \mathrm{Mn}\left(18.06 \mu \mathrm{g} \mathrm{L}^{-1}\right), \mathrm{B}$ $\left(16.39 \mu \mathrm{g} \mathrm{L}^{-1}\right), \mathrm{Sr}\left(16.27 \mu \mathrm{g} \mathrm{L}^{-1}\right)$ and $\mathrm{Cu}\left(10.42 \mu \mathrm{g} \mathrm{L}^{-1}\right)$ as a trace elements have been detected in large quantities during the whole study period because of activities of road construction and metallurgy and steel industries.

\section{ACKNOWLEDGEMENTS}

The author would like to thank the TUBITAK MAM Environment and Cleaner Production Institute's laboratory heads and staff for their assistances in the experimental studies.

\section{CONFLICTS OF INTEREST}

No conflict of interest was declared by the author.

\section{REFERENCES}

[1] Tuncay, E., Aşkın, B., Yücel, T., "Spatial fluctuation of sulphur dioxide $\left(\mathrm{SO}_{2}\right)$ and particulate matter (PM) levels measured in Bursa", Gazi Uni. J. Sci., 19(3): 143-148, (2006).

[2] Tiwari, S., Kulshrestha, U.C., Padmanabhamurty, B., "Monsoon rain chemistry and source apportionment using receptor modelling in and around National Capital Region (NCR) of Delhi, India", Atmos. Environ., 41(27): 5595-5604, (2007).

[3] Martins, E.H., Nogarotto, D.C., Mortatti, J., Pozza, S.A., "Chemical composition of rainwater in an urban area of the southeast of Brazil", Atmos. Pollut. Res., 10: 520-530, (2019).

[4] Prathibha, P., Kothai, P., Saradhi, I.V., Pandit, G.G., Puranik, V.D., "Chemical characterization of precipitation at a coastal site in Trombay, Mumbai, India", Environ. Monit. Assess., 168: 45-53, (2010).

[5] Shen, W., Ren, H., Jenerette, G.D., Hui, D., Ren, H., "Atmospheric deposition and canopy exchange of anions and cations in two plantation forests under acid rain influence", Atmos. Environ., 64: 242$250,(2013)$.

[6] De Oliveira Jr., R.C., Keller, M.M., Ramos, J.F.F., Beldini, T.P., Crill, P.M., Camargo, P.B., Van Haren, J., "Chemical analysis of rainfall and throughfall in the Tapajós national forest, Belterra, Pará, Brazil”, Ambiente e Agua - An Interdisciplinary J. Appl. Sci., 10(2): 263-285, (2015).

[7] Gonzáles, C.M., Aristizábal, B.H., "Acid rain and particulate matter dynamics in a mid-sized Andean city: the effect of rain intensity on ion scavenging", Atmos. Environ., 60: 164-171, (2012).

[8] Cangemi, M., Madonia, P., Favara, R., "Chemical characterisation of rainwater at Stromboli Island (Italy): the effect of post-depositional processes”, J. Volcanol. Geoth. Res., 335: 82-91, (2017).

[9] Naik, M.S., Momin, G.A., Rao, P.S.P., Safai, P.D., Ali, K., "Chemical composition of rainwater around an industrial region in Mumbai", Curr. Sci., 82(9): 1131-1137, (2002).

[10] Fornaro, A., Gutz, I.G.R., "Wet deposition and related atmospheric chemistry in the São Paulo metropolis, Brazil: Part 2-Contribution of formic and acetic acids", Atmos. Environ., 37(1): 117-128, (2003).

[11] Migliavacca, D., Teixeira, E.C., Pires, M., Fachel, J., "Study of chemical elements in atmospheric precipitation in South Brazil", Atmos. Environ., 38 (11): 1641-1656, (2004). 
[12] Coelho, C.H., Allen, A.G., Fornaro, A., Orlando, E.A., Grigoletto, T.L.B., Campos, M.L.A.M., "Wet deposition of major ions in a rural area impacted by biomass burning emissions", Atmos. Environ., 45(30): 5260-5265, (2011).

[13] Rodrigues, R.A.R., Mello, W.Z., Souza, P.A., "Atmospheric deposition of ammonium, nitrate ans sulfate on the montane dense ombrophilous forest in Serra dos Órgãos, RJ", Quím. Nova, 30(8): 1842-1848, (2007).

[14] Moreda-Piñeiro, J., Alonso-Rodríguez, E., Moscoso-Pérez, C., Blanco-Heras, G., Turnes-Carou, I., López-Mahía, P., Muniategui-Lorenzo, S., Prada-Rodríguez, D., "Influence of marine, terrestrial and anthropogenic sources on ionic and metallic composition of rainwater at a suburban site (northwest coast of Spain)". Atmos. Environ., 88: 30-38, (2014).

[15] Lee, B.K., Hong, S.H., Lee, D.S., "Chemical composition of precipitation and wet deposition of major ions on the Korean peninsula", Atmos. Environ., 34: 563- 575, (2000).

[16] Baron, J., Denning, A.S., "The influence of mountain meteorology on precipitation chemistry at low and high elevations of the Colorado Front Range, USA", Atmos. Environ. Part A-General Topics, 27: 2337-2349, (1993).

[17] Cerqueira, M.R.F., Pinto, M.F., Derossi, I.N., Esteves, W.T., Santos, M.D.R., Matos, M.A.C., Lowinsohn, D., Matos, R.C., "Chemical characteristics of rainwater at a southeastern site of Brazil", Atmos. Pollut. Res., 5: 253-261, (2014).

[18] Zunckel, M., Saizar, C., Zarauz, J., "Rainwater composition in Northeast Uruguay", Atmos. Res., 37: 1601-1611, (2003).

[19] Bahattin, C., İbrahim, K., "The Relation between Meteorological Factors and Pollutants Concentrations in Karabük City", Gazi Uni. J. Sci., 20(4): 87-95 (2007).

[20] Herrera, J., Rodríguez, S., Baéz, A., "Chemical composition of bulk precipitation in the metropolitan area of Costa Rica, Central America", Atmos. Res., 94: 151-160, (2009).

[21] Hoinaski, L., Franco, D., Haas, R., Martins, R.F., Lisboa, H.M., "Investigation of rainwater contamination sources in the southern part of Brazil", Environ. Technol., 35(7):868-881, (2014).

[22] Wang, L., Chen, Z., Shang, H., Wang, J., Zhang, P.Y., "Impact of simulated acid rain on soil microbial community function in Masson pine seedlings", Electr. J. Biotechnol., 17(5): 199-203, (2014).

[23] Alcolea, A., Fernández-López, C., Vázquez, M., Caparrós, A., Ibarra, I., García, C., Zarroca, M., Rodríguez, R., "An assessment of the influence of sulfidic mine wastes on rainwater quality in a semiarid climate (SE Spain)", Atmos. Res., 107: 85-94, (2015).

[24] Al-Khashman, O.A., "Chemical characteristics of rainwater collected at a western site of Jordan", Atmos. Res., 91: 53-61, (2009).

[25] Huang, X.F., Li, X., He, L.Y., Feng, N., Hu, M., Niu, Y.W., Zeng, L.W., "5-Year study of rainwater chemistry in a coastal mega-city in South China", Atmos. Res., 97: 185-193, (2010).

[26] Laouali, D., Galy-Lacaux, C., Diop, B., Delon, C., Orange, D., Lacaux, J.P., Akpo, A., Lavenu, F., Gardrat, E., Castera, P., "Long term monitoring of the chemical composition of precipitation and wet deposition fluxes over three Sahelian savannas", Atmos. Environ., 50: 314-327, (2012). 
[27] Abdus-Salam, N., Adekola, F.A., Otuyo-Ibrahim, M., "Chemical composition of wet precipitation in ambient environment of Ilorin, north central Nigeria", J. Saudi Chem. Soc., 18: 528-534, (2014).

[28] Sánchez, A.S., Cohim, E., Kalid, R.A., "A review on physicochemical and microbiological contamination of roof-harvested rainwater in urban areas", Sustain. Water Qual. Ecol., 6: 119-137, (2015).

[29] Roy, A., Chatterjee A., Tiwari, S., Sarkar, C., Das, S.K., Ghosh, S.K., Raha, S., "Precipitation chemistry over urban, rural and high altitude Himalayan stations in eastern India", Atmos. Res., 18: 44-53, (2016).

[30] Mimura, A.M.S., Almeida, J.M., Vaz, F.A.S., de Oliveira, M.A.L., Ferreira, C.C.M., Silva, J.C.J., "Chemical composition monitoring of tropical rainwater during a typical dry year", Atmos. Res., 169: 391-399, (2016).

[31] Mehr, M.R., Keshavarzi, B., Sorooshian, A., "Influence of natural and urban emissions on rainwater chemistry at a southwestern Iran coastal site", Sci. Total Environ., 668: 1213-1221, (2019).

[32] Vlastos, D., Antonopoulou, M., Lavranou, A., Efthimiou, I., Dailianis, S., Hela, D., Lambropoulou, D., Paschalidou, A.K., Kassomenos, P., "Assessment of the toxic potential of rainwater precipitation: First evidence from a case study in three Greek cities”, Sci. Total Environ., 648: 1323-1332, (2019).

[33] Garaga, R., Chakraborty, S., Zhang, H., Gokhale, S., Xue, Q., Kota, S.H., "Influence of anthropogenic emissions on wet deposition of pollutants and rainwater acidity in Guwahati, a UNESCO heritage city in Northeast India", Atmos. Res., 232: 104683, (2020).

[34] GDM, "General Statistics data of our provinces", General Directorate of Meteorology, (2020). https://www.mgm.gov.tr/tahmin/il-ve-ilceler.aspx?il=Kocaeli\&ilce=Gebze. (In Turkish).

[35] APHA, AWWA and WEF, "Standard Methods for the Examination of Water and Wastewater", American Public Health Association, Washington, DC, (2012).

[36] Charlson, R., Rodhe, H., "Factors controlling the acidity of natural rainwater", Nature, 295: 683-685, (1982).

[37] Zhao, M., Li, L., Liu, Z., Chen, B., Huang, J., Cai, J., Deng, S., "Chemical composition and sources of rainwater collected at a semi-rural site in Ya'an, southwestern China", Atmos. and Clim. Sci., 3: 486-496, (2013).

[38] Demirak, A., Balci, A., Karaoğlu, H., Tosmur, B., "Chemical characteristics of rain water at an urban site of south western Turkey”, Environ. Monit. Assess., 123: 271-283, (2006).

[39] Örnektekin, S., Cakmakli, S., "Chemical composition and acidity of rain at the gulf of Iskenderun, North-East Mediterranean”, Water, Air, \& Soil Pollut.: Focus, 3: 151-166, (2003).

[40] Gülsoy, G., Tayanç, M., Ertürk, F., "Chemical analyses of the major ions in the precipitation of İstanbul, Turkey”, Environ. Pollut., 105: 273-280, (1999).

[41] Demir, F.T., Kılıçer, Y.Ç., Yenisoy-Karakaş, S., "Yarı şehirsel istasyonda toplanan yağmur suyunun iyon kompozisyonunun belirlenmesi ve asitlik", VII. Ulusal Hava Kirliliği ve Kontrolü Sempozyumu, Antalya, Turkey, 873-882, (2017). 
[42] Kaya, G., Tuncel, G., "Trace element and major ion composition of wet and dry deposition in Ankara, Turkey”, Atmos. Environ., 31: 3985-3998, (1997).

[43] Özsoy, T., Türker, P., Örnektekin, S, "Precipitation chemistry as an indicator of urban air quality in Mersin, North-Eastern Mediterranean region”, Water Air \& Soil Pollut., 189: 69-83, (2008).

[44] Al-Momani, I.F., Ataman, O.Y., Anwari, M.A., Tuncel, S., Köse, C., Tuncel, G., "Chemical composition of precipitation near an industrial area at İzmir, Turkey", Atmos. Environ., 29: 11311143, (1995).

[45] Akkoyunlu, B.O., Tayanç, M., Karaca, M., "Analysis of bulk and sub-event wet deposition in Gebze", 2nd International Symposium on Air Quality Management at Urban, Regional and Global Scales, Istanbul, Turkey, 509-516, (2001).

[46] Tang, J., Xue, H., Yu, X., Cheng, H., Xu, X., Zhang, X., Ji, J., “The preliminary study on chemical characteristics of precipitation at Mt. Waliguan", Acta Sci. Circum., 20(4): 420-425, (2000). (in Chinese).

[47] Zhang, M., Wang, S., Wu, F., Yuan, X., Zhang, Y., "Chemical compositions of wet precipitation and anthropogenic influences at a developing urban site in southeastern China". Atmos. Res., 84(4): 311 $322,(2007)$.

[48] Lu, X., Li, L. Y., Li, N., Yang, G., Luo, D., Chen, J., "Chemical characteristics of spring rainwater of Xi'an city", NW China", Atmos. Environ., 45: 5058-5063, (2011).

[49] Souza, P.A., Mello, W.Z., Maldonado, J., "Composição química da chuva e aporte atmosférico na Ilha Grande, RJ”, Quím. Nova, 29(3): 471-476, (2006).

[50] Vieira-Filho, M.S., Pedrotti, J.J., Fornaro, A., "Contribution of long and mid-range transport on the sodium and potassium concentrations in rainwater samples, São Paulo megacity, Brazil", Atmos. Environ., 79: 299-307, (2013).

[51] Tuncer, B., Bayar, B., Yeşilyurt, C., Tuncel, G. "Ionic composition of precipitation at the Central Anatolia (Turkey)", Atmos. Environ., 35: 5989-6002, (2001).

[52] Calvo, A.I., Olmo, F.J., Lyamani, H., Alados-Arboledas, L., Castro, A., Fernández-Raga, M., Fraile, R., "Chemical composition of wet precipitation at the background EMEP station in Víznar (Granada, Spain) (2002-2006)", Atmos. Res., 96, 408-420, (2010).

[53] Shakya, K.M., Peltier, R.E., Shrestha, H., Byanju, R.M., "Measurements of TSP, PM10, PM2.5, BC, and PM chemical composition from an urban residential location in Nepal", Atmos. Pollut. Res., 8: 1123-1131, (2017).

[54] Tsai, Y.I., Hsieh, L.Y., Kuo, S.C., Chen, C.H., Wu, P.W., "Seasonal and rainfall-type variations in inorganic ions and dicarboxylic acids and acidity of wet deposition samples collected from subtropical East Asia". Atmos. Environ., 45(21): 3535-3547, (2011).

[55] Dordevic, D., Mihajlidi-Zelic, A., Relic, D., "Differentiation of the contribution of local resuspension from that of regional and remote sources on trace elements content in the atmospheric aerosol in the Mediterranean area", Atmos. Environ., 39(34): 6271-6281, (2005).

[56] Reimann, C., Caritat, P., "Chemical Elements in the Environment, Factsheets for the Geochemist and Environmental Scientist", 398, (1998). 
[57] Lin, X., He, L., Zhang, R., Guo, X., Li, H., "Rainwater in Guangzhou, China: Oxidizing properties and physicochemical characteristics", Atmos. Pollut. Res., 10: 303-312, (2019).

[58] Song, F., Gao, Y., "Chemical characteristics of precipitation at metropolitan Newark in the US East Coast", Atmos. Environ., 43: 4903-4913, (2009).

[59] Senevirathna, S., Ramzan, S., Morgan, J., "A sustainable and fully automated process to treat stored rainwater to meet drinking water quality guidelines", Process Saf. Environ. Prot., 130: 190-196, (2019).

[60] Samara, C., Tsitouridou, R., Balafoutis, C.H., "Chemical composition of rain in Thessaloniki, Greece, in relation to meteorological conditions", Atmos. Environ., 26(3): 359-367, (1992).

[61] Topcu, S., Incecik, S., Atimtay, A., "Chemical composition of rainwater at EMEP station in Ankara, Turkey", Atmos. Res., 65:77-92, (2002).

[62] Al-Momani, I.F., Aygun, S., Tuncel, G., "Wet deposition of major ions and trace elements in the Eastern Mediterranean basin”, J. Geophys. Res., 103: 8287-8299, (1998).

[63] Al-Momani, I.F., "Trace elements in atmospheric precipitation at Northern Jordan measured by ICPMS: acidity and possible sources", Atmos. Environ., 37: 4507-4515, (2003).

[64] Kulshrestha, U.C., Kulshrestha, M.J., Sekar R., Sastry, G.S.R., Vairamani, M., "Chemical characteristics of rainwater at an urban site of south-central India", Atmos. Res., 37: 3019-3026, (2003).

[65] Cao, Y., Wang, S., Zhang, G., Luo, J., Lu, S., "Chemical characteristics of wet precipitation at an urban site of Guangzhou, South China", Atmos. Res., 94: 462-469, (2009).

[66] Taylor, S.R., "Abundance of chemical elements in the continental crust: a new table", Geochim. Cosmochim. Acta, 28(8): 1273-1285, (1964).

[67] Poissant, L., Schmit, J.-P., Béron, P., "Trace inorganic elements in rainfall in the Montreal Island", Atmos. Environ., 28(2): 339-346, (1994).

[68] Singh, K.P., Singh, V.K., Malik, A., Sharma, N., Murthy, R.C., Kumar, R., "Hydrochemistry of wet atmospheric precipitation over an urban area in Northern Indo-Gangetic Plains", Environ. Monit. Assess., 131(1), 237-254, (2007). 